Penerimaan Dukungan Sosial Sebagai Prediktor Resiliensi

pada Tenaga Kesehatan di Masa Pandemi COVID-19

Proyeksi, Vol. 16 (2) 2021, 119-132

\title{
PENERIMAAN DUKUNGAN SOSIAL SEBAGAI PREDIKTOR RESILIENSI PADA TENAGA KESEHATAN DI MASA PANDEMI COVID 19
}

\author{
Dina Syakina \\ Fakultas Psikologi Universitas Mercubuana Jakarta, Jalan Meruya Selatan No. 1, Kembangan, Jakarta Barat \\ E-mail: dina.syakina@mercubuana.ac.id
}

\begin{abstract}
Abstrak
Penelitian ini memiliki tujuan untuk mengetahui hubungan penerimaan dukungan sosial dengan resiliensi tenaga kesehatan di masa pandemi COVID-19. Penerimaan dukungan sosial dipahami sebagai dukungan yang bersumber dari keluarga, teman, dan significant others, yang mengacu pada cakupan jaringan sosial yang dimiliki individu sebagai tempat mendapatkan dukungan. Penelitian ini menggunakan teknik sampling aksidental (Accidental Sampling). Responden dalam penelitian ini ditujukan pada tenaga kesehatan yang menghadapi, merawat, berinteraksi, maupun ikut serta/terlibat dalam penanganan pasien COVID-19 yang berjumlah 112 responden.Penelitian ini merupakan penelitian kuantitatif dengan menggunakan uji regresi berganda. Skala yang digunakan dalam penelitian ini adalah skala Multidimensional perceived social support scale oleh Zimet (1988), dan skala Connor Davidson Resilience scale 25 oleh Connor dan Davidson (2003). Hasil penelitian menunjukkan bahwa persepsi dukungan sosial berkontribusi sebesar 33,2 persen $(p<0.01)$ terhadap resiliensi frontliners tenaga kesehatan di masa pandemi COVID-19, dimana penerimaan dukungan sosial yang berasal dari teman $(\beta=0.235$; $p<0.05)$ dan significant others $(\beta=0.261 ; p<0.05)$ memiliki hubungan signifikansi positif dengan resiliensi, yang berarti tingginya penerimaan dukungan sosial teman dan significant others maka resiliensi meningkat.
\end{abstract}

Kata kunci : Perceived social support, Resiliensi, Tenaga Kesehatan, Pandemi COVID-19

\section{PERCEIVED SOCIAL SUPPORT AS A PREDICTOR OF RESILIENCE ON HEALTH PERSONNEL FRONTLINERS DURING THE COVID-19 PANDEMIC}

\begin{abstract}
This study aimed to determine the relationship between perceptions of social support and the resilience of health workers during the COVID-19 pandemic. Perception of social support is understood as support that comes from family, friends, and significant other, which refers to the scope of social networks owned by individuals as a place to get support. This research uses accidental sampling technique (Accidental Sampling). Respondents in this study were aimed at health workers who faced, treated, interacted, and participated/involved in handling COVID-19 patients, totaling 112 respondents. This research is a quantitative research using multiple regression analysis. The scale used in this study is the Multidimensional perceived social support scale by Zimet (1988), and the Connor Davidson Resilience Scale by Connor and Davidson (2003). The results showed that perceptions of social support contributed 33.2 percent $(p<0.01)$ to the resilience of health workers during the COVID-19 pandemic, where perceived of social support from friends $(B=0.235 ; p<0.05)$ and significant others. $(B=0.261 ; p<0.05)$ have positive significance relationship with resilience, which means that the higher the perceived of friends social support and significant others, the resilience increases.
\end{abstract}

Keywords: Perceived social support, Resilience, Health Workers, Pandemic COVID-19 


\section{Pendahuluan}

Pandemi COVID-19 yang melanda dunia telah mengakibatkan kematian ratusan ribu jiwa termasuk Indonesia yang telah kehilangan 12.027 jiwa (Kemenkes, 2020; Ourworldindata, 2020), termasuk didalamnya tenaga kesehatan diantaranya 123 dokter dan 80 perawat menjadi korban dari penyebaran coronavirus (CNN Indonesia, 2020; Kompas, 2020). Tidak hanya mengakibatkan kematian, pandemi COVID-19 juga memberikan penambahan beban psikologis bagi tenaga kesehatan (Lee et al., 2007; Maunder et al., 2003) seperti depresi dan kecemasan (Lai et al., 2020), dan stress yang tinggi juga dirasakan tenaga kesehatan selama pandemi COVID-19 (Rossi et al., 2020) yang diakibatkan oleh penambahan jumlah pasien yang mengakibatkan bertambahnya jam kerja, kurangnya Alat Pelindung Diri (APD), prosedur ketat kesehatan, isolasi sosial, ketakutan menularkan virus pada keluarga (Heath, Sommerflied, \& Sternberg, 2020; Putri \& Anulus, 2020). Kelompok tenaga kesehatan yang merupakan kelompok beresiko tinggi diharuskan bertahan untuk dapat tetap berkerja dengan baik. Oleh karena itu, tenaga kesehatan memerlukan daya tahan juang yang tinggi untuk bertahan dikondisi yang penuh dengan rasa cemas dan stres (Nursing Times, 2020), sering kali berdampak kepada kesehatan mental bila tidak teratasi dengan baik (Bozdag \& Ergun, 2020; Setiawati et al., 2021).

Didefinisikan oleh Connor dan Davidson (2003) sebagai daya juang yang dimiliki seorang individu untuk bertahan dan berkembang menghadapi kesulitan, resiliensi juga dipahami sebagai kapasitas individu dalam beradaptasi terhadap sebuah gangguan ataupun situasi sulit (Masten, 2013). Terkait hubungan resiliensi dengan pandemi, resiliensi juga diidentifikasi sebagai faktor esensial yang digunakan sebagai pelindung diri dalam menghadapi dampak mental psikologis dari kejadian traumatis seperti bencana alam, situasi darurat, dan wabah infeksi penyakit (Labrague, 2021; Pollock et al., 2020). Selain itu penelitian yang dilakukan kepada perawat yang bekerja di unit klinis selama pandemi COVID-19 yang memiliki tingkat resiliensi rendah resiliensi berakibat pada kemampuan coping stress yang kurang baik (Kim et al., 2019; Roberts et al., 2021). Sebaliknya, tingginya resiliensi yang dimiliki tenaga kesehatan dapat membuat perubahan positif, seperti mampu menyesuaikan kondisi psikologis mereka dengan baik dalam menilai suatu masalah atau tekanan yang dihadapi (Guo et al., 2017) serta meningkatkan upaya mempersiapkan strategi untuk menghadapi masa sulit (Manomenidis, Panagopoulou, \& Montgomery, 2018). Oleh karena itu, tidak heran banyak institusi kesehatan yang berupaya untuk membangun intervensi dan program untuk meningkatkan resiliensi agar kinerja dan kesehatan mental tetap terjaga (Adimando, 2018; Lebrague \& de los Santos, 2020).

Connor dan Davidson (2003) mengukur resiliensi melalui faktor yang mencakup; (1) kompetensi pribadi, standar yang tinggi dan kegigihan; (2) kepercayaan diri, toleransi terhadap efek negatif, kuat bertahan menghadapi stres; (3) penerimaan positif terhadap perubahan, hubungan baik dengan orang lain, secure attachment; (4) control; (5) pengaruh spiritual. Sehingga, resiliensi sering dianggap sebagai sumberdaya personal yang harus dimiliki oleh tenaga kesehatan, terutama dalam menghadapi kondisi yang penuh dengan ketidakpastian seperti saat menghadapi pandemi COVID 19. Terdapat beberapa faktor yang membedakan tingkat resiliensi setiap individu, faktor internal mencakup (1) usia; (2) jenis kelamin; (3) edukasi; (4) status marital; (5) kepribadian meliputi, emosi, kognitif, intelegensi, tempramen, kemampuan adaptasi dan sosial (Khanlou \& Wray, 2014); dan faktor eksternal, yaitu lingkungan, meliputi penerimaan dukungan sosial (Herrman et al., 2011).

Dari berbagai faktor yang menyebabkan tingkat resiliensi berbeda pada individu, faktor eksternal yaitu dukungan sosial dianggap menjadi salah satu faktor penting dalam membangun resiliensi terutama bagi tenaga kesehatan, karena dianggap mampu melindungi dari stres dan cemas 
menghadapi masa sulit (Cao \& Chen, 2019; Labrague \& De los Santos, 2021). Menurut Zimet, Dahlem, Zimet, dan Farley (1988) penerimaan dukungan sosial didefinisikan sebagai persepsi individu tentang bagaimana sumber daya dapat bertindak sebagai penahan antara peristiwa dan gejala stres, yang bersumber dari (1) keluarga meliputi orang tua, pasangan, mertua, saudara (Astuti, Santosa, \& Utami, 2000; Fatima, Sharif, \& Zimet, 2018); (2) teman, meliputi orang terdekat dengan usia yang tidak jauh berbeda, memiliki hubungan erat, misal teman sekolah, tetangga dan (3) significant others adalah dukungan yang bersumber dari seseorang yang dianggap penting tergantung pada jaringan sosial yang ada, sebagai contoh meliputi rekan kerja, atasan (Santoso \& Setiawan, 2018). Beberapa penelitian terdahulu menyatakan bahwa tenaga kesehatan yang menerima dukunga sosial cenderung memiliki resiliensi yang tinggi, yang juga meningkatkan control terhadap perasaan negatif terhadap kondisi penuh tekanan (Kılınç \& Çelik, 2020). Penerimaan social support yang didapat tenaga kesehatan dari keluarga terutama pasangan dapat meningkatkan resiliensi dalam menghadapi tekanan beban kerja (Ang et al., 2018). Waddimba et al., (2016) mengatakan penerimaan dukungan sosial rekan sejawat, berefek pada kesejahteraan dalam bekerja, dan mengurangi efek negatif dari stres pada tenaga kesehatan (Fu et al., 2017). Dukungan sosial dari keluarga dan teman meningkatkan resiliensi yang mempercepat pemulihan akibat trauma (Hsieh, Chang, \& Wang, 2017).

Tidak diragukan bahwa hasil penelitian terdahulu menunjukkan penerimaan dukungan sosial berhubungan dengan resiliensi, namun kenyataannya dalam menghadapi pandemi COVID 19 para tenaga kesehatan tidak mudah untuk memperoleh dukungan sosial, hal tersebut dikarenakan kekhawatiran tenaga kesehatan akan potensi penularan, kematian yang tinggi, serta ketakutan terinfeksi dan menularkan pada keluarga (Hendy, et al. 2020). Sejalan dengan penelitian Hu et al., (2020) kepada 1324 perawat yang bekerja di Wuhan (tempat diindikasikan awalnya penularan coronavirus 2019) menyatakan bahwa sebagian besar perawat ketakutan dan depresi karena menghadapi pandemi terlebih takut menularkannya kepada orang terdekat. Hal tersebut mengindikasikan adanya dilema diantara tanggung jawab sebagai tenaga kesehatan, sementara di satu sisi mereka butuh untuk melindungi diri dan orang lain dari ancaman virus (Maben \& Bridges, 2020) membuat para tenaga kesehatan cenderung memilih untuk membatasi interaksi dalam memperoleh dukungan sosial yang berakibat pada kurangnya komunikasi yang terjalin dengan keluarga dan lingkungan sosial (Talaee et al, 2020). Bahkan beberapa dari tenaga kesehatan mengaku sangat sulit konsisten untuk sekedar membalas pesan teks kepada keluarganya (Viswanathan, Myers, \& Fanous, 2020) karena jam kerja yang panjang dan tak menentu.

Sulitnya mendapatkan dukungan sosial baik dari keluarga, teman, dan rekan sejawat membuat para tenaga kesehatan merasa bekerja dalam rasa terisolasi yang mengakibatkan rendahnya level psikososial kerja dan menurunkan kinerja tenaga kesehatan (Bry \& Wigert, 2021) yang mengindikasikan menurunkan resiliensi. Sementara Hu et al., (2020) menyatakan bahwa cukupnya dukungan sosial yang diterima tenaga kesehatan meningkatkan kesehatan mental dan berjung pada meningkatnya resiliensi. Maka perlu ditelaah bagaimana pengaruh penerimaan dukungan sosial yang diterima oleh tenaga kesehatan pada saat pandemi COVID 19.

Berdasarkan penjelasan latar belakang maka penelitian ini bertujuan unutk mengetahui bagaimana pengaruh penerimaan dukungan sosial yang berasal dari keluarga, teman, dan significant others terhadap resiliensi tenaga kesehatan pada tenaga kesehatan dimasa pandemi COVID-19. Hipotesis penelitian ini adalah $(\mathrm{H} 1)$ terdapat pengaruh antara penerimaan dukungan sosial keluarga terhadap resiliensi tenaga kesehatan; $(\mathrm{H} 2)$ terdapat pengaruh antara penerimaan dukungan sosial 
teman terhadap resiliensi tenaga kesehatan; serta (H3) terdapat pengaruh antara penerimaan dukungan sosial significant others terhadap resiliensi tenaga kesehatan saat pandemic COVID 19.

\section{Metode Penelitian}

Penelitian ini menggunakan desain penelitian kuantitatif, dengan tipe penelitian korelasional prediktif untuk mengetahui pengaruh antara dua variabel. Metode penelitian kuantitatif dipahami penelitian yang memberikan deskripsi berupa angka atau secara kuantitatif tentang sikap, tren, atau opini suatu populasi melalui sample dari populasi tersebut (Creswell, 2014). Sedangkan tipe penelitian yang digunakan yaitu korelasional, yang mana penelitian korelasional melibatkan pengamatan dua atau lebih variabel dan menentukan hubungan apa diantara mereka (Bordens \& Abbott, 2011).

Populasi dari penelitian ini merupakan tenaga kesehatan dan sampel penelitian merupakan tenaga kesehatan yang menghadapi, merawat, berinteraksi atau ikut serta dalam penanganan pasien COVID-19 di Jabodetabek. Tenaga kesehatan menurut WHO dan Frontliner Health Worker, tenaga kesehatan adalah personel atau individu yang mengabdikan diri dalam bidang kesehatan dan merupakan pihak terdepan yang berinteraksi secara langsung dengan masyarakat yang tercakup di dalamnya yaitu perawat, dokter, asisten kesehatan yang bekerja dibawah supervisi tenaga kesehatan. Sebanyak 122 responden tenaga kesehatan berpartisipasi dalam penelitian ini diperoleh dari teknik aksidental sampling yang dipahami sebagai sampel yang dipilih berdasarkan situasi dan waktu yang tepat.

Penelitian ini menggunakan metode survey dalam pengumpulan data dengan cara mengisi instrumen penelitian yang sebelumnya telah melalui tahapan forward translation dan tahapan Expert Judgement (untuk menguji keterbacaan dan pemahaman alat ukur). Semua instrumen yang digunakan dalam penelitian disesuaikan dengan konteks pandemic COVID-19 dan diukur dengan menggunakan skala likert ( 1 = sangat tidak sesuai hingga 5 = sangat sesuai). Instrumen pengukuran variabel penerimaan dukungan sosial menggunakan Multidimensional Perceives Support Scale milik Zimet (1988) dengan 12 item yang mengukur 3 dimensi yaitu 4 aitem untuk mengukur dimensi keluarga ("Selama pandemi berlangsung keluarga saya sangat mencoba membantu"); 4 aitem untuk mengukur dimensi teman ("Saya bisa menceritakan masalah saya pada teman selama pandemi berlangsung"), dan 4 aitem untuk mengukur dimensi significant others ("Ada orang special yang bisa berbagi suka dan duka dengan saya selama pandemi COVID-19"). Instrumen yang digunakan mengukur resiliensi yaitu CD-RISC 25 (Connor Davidson Resilience Scale) yang meliputi 25 item dengan 5 aspek pengukuran, yaitu (1) 4 aitem untuk mengukur kompetensi pribadi ("saya berpikir bahwa saya adalah seseorang yang kuat"), (2) 6 aitem untuk mengukur kepercayaan diri ("saya cenderung bangkit kembali setelah mengalami kesakitan atau kesulitan"), (3) 6 aitem untuk mengukur penerimaan positif terhadap perubahan ("Saya tetap memiliki hubungan dekat dan kuat dengan orang lain"), (4) 5 aitem mengukur kontrol ("saya mampu untuk mengontrol hidup saya"), dan (5) 4 aitem untuk mengukur pengaruh spiritual ("terkadang keyakinan pada tuhan dapat membantu saya").

Sebelum melakukan field study, terlebih dahulu dilakukan uji coba penelitian. Langkah pertama, dilakukan uji coba pada tenaga kesehatan di wilayah Jabodetabek yang menangani atau ikut serta terlibat dalam penanganan pasien COVID-19, disebarkan melalui survai secara daring dengan menggunakan google form dan berhasil mengumpulkan sebanyak 49 responden. Hasil uji coba digunakan untuk menguji reliabilitas dan validitas alat ukur sebelum melakukan uji turun lapang. Hasil 
uji reliabilitas pada instrumen penelitian baik pada uji coba dan turun lapang menggunakan alpha cronbach $(\alpha)$ dan uji validitas menggunakan validitas konstruk.

Instrumen Multidimensional Perceive Support Scale, memiliki rentang alpha cronbach ( $\alpha) 0.872$ hingga 0.967 untuk uji coba dan memiliki rentang alpha cronbach ( $\alpha$ ) 0.815 hingga 0.928 . Berdasarkan cut off alpha cronbach $(\alpha)$ reliabilitas yang digunakan dalam penelitian ini terkategori reliabel. Kemudian untuk uji validitas uji coba dilihat berdasarkan nilai Pearson correlation ( $r>0.30$ ) yang berada pada rentang nilai Pearson correlation ( $r$ ) $0.600 \mathrm{~s} / \mathrm{d} 0.917$ dan dinyatakan valid. Sementara uji validitas turun lapang pada instrumen yang sama didapatkan dengan nilai nilai $r>0,2$ berada direntang 0,584 hingga 0,812 yang dapat dinyatakan valid.

Hasil uji reliabilitas pada instrument Connor Davidson Resilience Scale didapatkan alpha cronbach ( $\alpha$ ) sebesar 0.929 dan untuk uji turun lapang sebesar 0.914, sehingga dinyatakan reliable. Selanjutnya, dalam uji validitas pada saat uji coba instrumen ini memiliki nilai pearson correlation yang berada dalam rentang nilai dari 0.378 hingga 0.898 lebih besar dari nilai $r>0.30$, dari 25 aitem yang diikutsertakan dalam pengujian uji coba hanya 19 item yang bertahan. Namun, pada saat turun lapang tidak terdapat aitem yang terbuang saat uji validitas dengan rentang nilai 0.355 hingga $0.788(r>0,2)$.

Metode analisis data dalam penelitian ini yang meliputi uji hipotesis dengan menggunakan regresi linier berganda. Selain itu diperoleh juga data tambahan untuk menunjang hasil penelitian seperti uji T-test dan uji korelasi diperoleh dengan bantuan perangkat lunak analisis data Jamovi 1.6.8

\section{Analisis dan Intepretasi Data}

Berdasarkan hasil analisis didapatkan bahwa dari 112 responden penelitian, responden didominasi oleh tenaga kesehatan yang berjenis kelamin perempuan (78.6\%) dan satu perlimanya adalah laki-laki (21.4\%). Selain itu, relawan atau volunteer memiliki proporsi terbanyak sebagai responden (32.1\%) diikuti oleh perawat sebanyak 24.1 persen, dokter dengan persentase sebesar $11.6 \%$, dan bekerja sebagai staf farmasi sebesar 3.5\% dengan persentase terendah.

Berdasarkan uji t-test, didapatkan bahwa Independent $T$-test yang dilakukan antara penerimaan dukungan sosial dengan jenis kelamin didapatkan hasil signifikansi diatas 0.05 ( $t=0.926, p=0.456$ > $0.05)$, yang berarti tidak terdapat perbedaan. Sehingga dapat dinyatakan bahwa pada variabel penerimaan dukungan sosial untuk jenis kelamin perempuan dan laki-laki tidak memiliki perbedaan yang bermakna.

Tabel 1. Kategorisasi Skor Variabel

\begin{tabular}{lccc}
\hline \multicolumn{1}{c}{ Variabel } & \multicolumn{3}{c}{ Kategori } \\
\cline { 2 - 4 } & Tinggi & Sedang & Rendah \\
\hline Penerimaan Dukungan Sosial Keluarga & $18(16.1 \%)$ & $78(69.6 \%)$ & $16(14.3 \%)$ \\
Penerimaan Dukungan Sosial Teman & $21(18.8 \%)$ & $82(73.2 \%)$ & $9(8.0 \%)$ \\
Penerimaan Dukungan Sosial sig. others & $23(20.5 \%)$ & $73(65.2 \%)$ & $16(14.3 \%)$ \\
Resiliensi & $23(20.5 \%)$ & $69(61.6 \%)$ & $20(17.9 \%)$ \\
\hline
\end{tabular}

Berdasarkan Tabel 1 dapat terlihat kategorisari tingkat penerimaan dukungan sosial yang dirasakan responden cukup seragam, yaitu berada dalam kategori sedang. Kategori penerimaan dukungan sosial yang berasal dari keluarga didominasi pada kategori sedang sebanyak 78 responden dengan persentase 69.6 persen, untuk penerimaan dukungan sosial teman dengan 82 responden 
dengan persentase 73.2 persen, dan untuk significant others (73 responden) sebesar 65.2 persen. Kategorisasi untuk tingkat resiliensi berada dalam kategori sedang sebesar 61.6\% (69 \%).

\section{Uji Hipotesis}

Sebelum dilakukannya uji hipotesis penelitian, terlebih dahulu dilakukan uji normalitas data dengan menggunakan Kolmogorov Smirnov (K-S). Dimana nilai signifikansi Kolmogorov Smirnov $>0,05$ dinyatakan data berdistribusi normal, sedangkan apabila nilai signifikansi Kolmogorov Smirnov < 0,05 maka data tidak dapat dinyatakan berdistribusi normal. Berdasarkan hasil uji normalitas didapatkan bahwa nilai Kolmogorov Smirnov sebesar $k s=1.012$ dengan signifikansi 0.257 ( $p>0.05$ ) hal ini menunjukkan bahwa data telah terdistribusi normal. Berdasarkan uji korelasi pearson (lihat Tabel 2) antar variabel ditemukan bahwa penerimaan dukungan sosial keluarga $(r=0.455, p<0.01)$, teman $(r=$ $0.459, p<0.01)$ dan significant others $(r=0.495, p<0.01$ ) memliki hubungan yang positif signifikan dengan resiliensi. Hasil tersebut menunjukkan bahwa semakin tinggi penerimaan dukungan sosial yang berasal dari keluarga, teman, dan significant others yang dirasakan oleh resonden, maka akan semakin tinggi resiliensi responden.

Tabel 1. Hasil Korelasi antar Variabel

\begin{tabular}{|c|c|c|c|c|c|c|}
\hline No & Variabel & 1 & 2 & 3 & 4 & 5 \\
\hline 1 & Resiliensi & 1 & & & & \\
\hline 2 & $\begin{array}{l}\text { Penerimaan Dukungan Sosial } \\
\text { Keluarga }\end{array}$ & $0.460 * *$ & 1 & & & \\
\hline 3 & $\begin{array}{l}\text { Penerimaan Dukungan Sosial } \\
\text { Teman }\end{array}$ & $0.472 * *$ & $0.454 * *$ & 1 & & \\
\hline 4 & $\begin{array}{l}\text { Penerimaan Dukungan Sosial sig. } \\
\text { others }\end{array}$ & $0.489 * *$ & $0.501 * *$ & $0.591 * *$ & 1 & \\
\hline 5 & Jenis kelamin & $0.071 *$ & -0.121 & -0.058 & -0.038 & 1 \\
\hline
\end{tabular}

Keterangan: ${ }^{* *} p<0.01 ;{ }^{*} p<0.05$

1= resiliensi; $2=$ Penerimaan Dukungan sosial keluarga; $3=$ penerimaan Dukungan Sosial Teman; $4=$ Penerimaan Dukungan Sosial sig. others; $5=$ Jenis Kelamin ( $1=$ laki-laki, $2=$ perempuan).

Selain itu korelasi antara resiliensi dengan jenis kelamin diperoleh nilai sebesar 0.071 dengan nilai signifikansi $p<0.05$. Hasil tersebut menandakan bahwa terdapat hubungan antara resiliensi dengan jenis kelamin. Namun, setelah dilakukan uji t-test untuk menguji beda tingkat resiliensi terhadap jenis kelamin, tidak ditemukan perbedaan yang signifikan ( $p>0.05$ ).

Uji hipotesis dilakukan dengan menguji pengaruh antara penerimaan dukungan sosial keluarga (X1), penerimaan dukungan sosial teman (X2) dan penerimaan dukungan sosial significant others (X3) terhadap resiliensi $(\mathrm{Y})$ dengan menggunakan uji regresi linier berganda. Berdasarkan Tabel 3 didapatkan hasil regresi linier berganda dengan koefisien determinasi $\left(R^{2}\right)$ sebesar $0.332(p<0.01)$, hasil tersebut menjelaskan bahwa penerimaan dukungan sosial yang berasal dari keluarga, teman, dan significant others dan nilai F sebesar 17.9 ( $p<0.01)$. Hasil tersebut menandakan bahwa penerimaan dukungan sosial keluarga, teman, dan significant others berkontribusi sebesar 33.2 persen varians terhadap resiliensi dan sisanya berasal dari variabel yang tidak diteliti dalam penelitian ini. 
Tabel 2 Hasil Regresi Linier Berganda

\begin{tabular}{lcc}
\hline \multicolumn{1}{c}{ Variabel } & B (estimate) & Keterangan Hipotesis \\
\hline Intercept & $55.885^{* *}$ & \\
Penerimaan Dukungan Sosial Keluarga & $0.771^{*}$ & H1 Diterima \\
Penerimaan Dukungan Sosial Teman & $0.801^{* *}$ & H2 Diterima \\
Penerimaan Dukungan Sosial sig. others & $0.687^{*}$ & H3 Diterima \\
\multicolumn{1}{c}{$\mathrm{R}^{2}$} & & $0.332^{* *}$ \\
\hline
\end{tabular}

Keterangan: ${ }^{* *} p<0.01 ;{ }^{*} p<0.05 ;$ Variabel $\mathrm{Y}$ (dependen)= Resiliensi

Berdasarkan hasil regresi linier berganda didapatkan bahwa penerimaan dukungan sosial keluarga $(B=0.771, p<0.05)$, penerimaan dukungan sosial teman $(B=0.801, p<0.01)$, dan penerimaan dukungan sosial significant others $(B=0.687, p<0.01)$ berpengaruh positif signifikan terhadap resiliensi. Hasil tersebut menandakan bahwa seluruh hipotesis dalam penelitian ini diterima, maka dapat dikatakan bahwa semakin tinggi penerimaan dukungan sosial yang berasal dari keluarga, teman, dan significant others maka semakin tinggi resiliensi yang dimiliki oleh tenaga kesehatan dalam mengahadapi pandemi COVID-19.

\section{Pembahasan}

Penelitian ini bertujuan untuk mengetahui apakah penerimaan dukungan sosial (keluarga, teman, dan significant others) berpengaruh terhadap resiliensi tenaga kesehatan dalam menghadapi pandemi COVID-19. Resiliensi didefinisikan sebagai proses yang di alami oleh individual, keluarga, dan komunitas untuk dapat beradaptasi dan menyesuaikan diri dengan baik saat dalam berada dalam tekanan (Ungar, 2012), salah satunya adalah dalam menghadapi pandemi COVID-19 yang menyebabkan tingkat stress yang dialami oleh tenaga kesehatan bertambah (Sanliturk, 2021). Mengalami penambahan dalam jumlah pasien yang mengakibatkan bertambahnya jumlah jam kerja (Labrague \& de los Santos, 2021) dan stigma sosial karena dianggap menularkan virus (Pasay-an, et al., 2021) tetapi pandemi menuntut tenaga kesehatan untuk tetap bekerja secara profesional membuat tenaga kesehatan diharapkan memiliki resiliensi yang baik (Duncan, 2020). Hasil penelitian ini mendukung teori penerimaan dukungan sosial milik Zimet, Dahlem, Zimet, dan Farley (1988) dan resiliensi milik Connor dan Davidson (2003) menyebutkan penerimaan dukungan sosial yang terbentuk karena adanya faktor pendukung yang didapat dari sumber dukungan sosial keluarga, teman, dan significant others dapat meningkatkan resiliensi.

Hasil penelitian menunjukkan bahwa semua dimensi penerimaan dukungan sosial berpengaruh signifikan terhadap resiliensi, maka semakin tinggi penerimaan dukungan sosial yang diterima oleh tenaga kesehatan maka semakin tinggi pula resiliensi mereka. Hasil penelitian ini sejalan dengan studi milik Dey dan Amponsah (2020) yang menyatakan bahwa terdapat hubungan antara penerimaan dukungan sosial dari keluarga, teman dan significant others dengan resiliensi. Berdasarkan deskriptif data analisis menunjukkan bahwa level resiliensi responden dalam penelitian ini berada dalam kategori sedang. Hal tersebut mengindikasikan bahwa semua responden merasa cukup yakin terhadap kompetensi pribadinya dalam menangani pekerjaannya selama pandemi, percaya diri dan mampu mengontrol emosi negatif dalam dirinya, dan secara spiritualitas percaya bahwa Tuhan akan menolong mereka dalam melakukan pekerjaan.

Tentunya resiliensi yang dimiliki oleh responden tidak serta merta terbentuk, hal tersebut terlihat dari data penelitian bahwa resiliensi berkorelasi positif signifikan dengan penerimaan dukungan sosial 
keluarga $(\mathrm{B}=0.771, \mathrm{p}<0.05)$ maka disimpulkan bahwa dukungan keluarga yang didapatkan menentukan tingkat resiliensi yang dimiliki tenaga kesehatan. Sesuai dengan hasil penelitian terdahulu yang menyebutkan bahwa penerimaan dukungan sosial yang berasal dari keluarga menjadi salah satu prediktor dari resiliensi (Lők \& Bademli, 2020). Data penelitian juga menunjukkan bahwa penerimaan dukungan sosial kerluarga yang diterima oleh tenaga kesehatan berada dalam kategori sedang, yanng mengindikasikan bahwa mereka mendapatkan dukungan yang cukup dari keluarga dalam melakukan pekerjaannya selama pandemi berlangsung serta keluarga percaya mereka semua mampu melalui masa sulit saat pandemi.

Penerimaan dukungan sosial teman menjadi prediktor paling besar jika dibandingkan dua dimensi penerimaan dukungan sosial yang lainnya $(B=0.801, p<0.01)$. Hal tersebut dapat diindikasikan bahwa tenaga kesehatan cenderung lebih banyak menghabiskan waktu selama pandemi di tempat mereka bekerja dibandingkan kembali ke rumah dan bertemu keluarga, sehingga dukungan yang berasal dari teman sangat dibutuhkan dalam menghadapi pandemi. Penelitian terdahulu milik Hamama et al., (2019) dan Winning et al., (2018) menyatakan bahwa dukungan sosial yang berasal dari tempat bekerja menjadi hal esensial dalam menghadapi tuntutan pekerjaan pada tenaga kesehatan. Studi kualitatif terhadap 15 responden yang dilakukan oleh Pasay-an et al., (2021) menyatakan bahwa, tidak hanya menghadapi tekanan dalam bekerja selama pandemi, para tenaga kesehatan juga terkadang mengalami stigma sosial seperti mendapat julukan "perawat COVID" dan dijauhi dari lingkungan sosial karena dianggap menularkan virus, sehingga dukungan emosional dari kolega dan rekan sejawat dipandang sebagai sumberdaya yang berharga bagi tenaga kesehatan (Bry \& Wigert, 2021). Responden dalam penelitian mempersepsikan mendapatkan penerimaan dukungan sosial dari teman dalam kategori sedang. Sehingga, dapat diindikasikan bahwa dukungan sosial dari teman yang didapatkan cukup baik, dimana teman atau kolega sesama tenaga kesehatan saling mendukung dan saling bertukar cerita suka duka selama bekerja. Penelitian terdahulu membuktikan bahwa seseorang mencari dan mendapatkan dukungan dari lingkungan sebagai pengganti support ketika seseorang berada diluar lingkup rumah (keluarga), yaitu berasal dari teman atau rekan sejawat (Tinajero et al., 2019)

Penerimaan dukungan sosial significant other dengan resiliensi yang memiliki hubungan yang signifikan $(B=0.687, p<0.05)$, membuktikan bahwa adanya dukungan dari significant other dapat menentukan resiliensi pada tenaga kesehatan saat menghadapi pandemi COVID-19. Data deskriptif juga menunjukkan bahwa responden dala penelitian ini merasa significant others cukup memberikan dukungan dalam menghadapi pandemi. Dukungan sosial significant others dapat berasal dari banyak pihak yang terkait dengan individu seperti atasan ditempat bekerja, sistem dan kebijakan organisasi yang terkait yang dirasa mampu dan dapat meningkatkan kemampuan dan daya tahan individu dalam menghadapi pandemi (Fatima, Sharif, \& Zimet, 2018; Fu et al., 2017; Mitchell \& Zimet, 2000). Studi terdahulu milik Hu et al., (2020) yang menyatakan bahwa sistem dan intervensi yang dimiliki oleh organisasi tempat tenaga kesehatan bekerja (pengetahuan dan pelatihan tentang menghadapi COVID19 dan call centre yang responsif) dapat membantu pekerjaan tenaga kesehatan menjadi lebih tertangani dengan baik. Selanjutnya, studi kualitatif millik Bry dan Wigert (2021) menyatakan bahwa tenaga kesehatan yang merasa bahwa atasan mereka memberikan dukungan sosial selama bekerja memiliki tingkat resiliensi yang lebih baik dan memiliki kontrol emosi yang baik pula. Penelitian lain juga menyatakan penerimaan dukungan sosial yang tinggi diterima dari significant other meningkatkan 
resiliensi (Aplizuddin, Harmayetti, \& Ulfiana, 2020). Hal tersebut berarti dengan adanya support dari significant other tenaga kesehatan memiliki resiliensi yang tinggi untuk menghadapi pandemi.

Korelasi antara resiliensi dengan jenis kelamin juga dijabarkan dalam penelitian ini dengan nilai korelasi yang signifikan $(r=0.071, \mathrm{p}<0.05)$, menunjukkan bahwa hubungan jenis kelamin dan resiliensi tenaga kesehatan berkorelasi positif, yang artinya resiliensi tenaga kesehatan dapat ditentukan berdasarkan jenis kelamin. Menyesuaikan pada hasil kategori jenis kelamin diketahui didominasi oleh jenis kelamin perempuan memiliki resiliensi sedang lebih banyak dibandingkan laki-laki. Sehingga dalam penelitian ini disimpulkan bahwa resiliensi tenaga kesehatan berjenis kelamin perempuan lebih tinggi dibandingkan dengan tenaga kesehatan berjenis kelamin laki-laki. Hasil ini berlawanan dengan penelitian milik Labrague dan de los Santos (2021) yang menyatakan bahwa gender tidak memengaruhi resiliensi. Namun, sejalan dengan hasil studi milik Jones, Woodward, \& Mioshi (2019) yang menyebutkan bahwa resiliensi perempuan cenderung lebih tinggi dibandingkan laki-laki.

Penelitian ini tidak mengikutsertakan data demografi lainnya seperti, usia dan status pernikahan. Hal tersebut berdasakan beberapa penelitian terdahulu yang berkaitan dengan topik dukungan sosial dengan resiliensi, menyatakan bahwa usia tidak memiliki hubungan secara signifikan untuk menggambarkan resiliensi (Sim, Bowes, \& Gardner, 2019) dan status marital tidak memiliki hubungan secara signifikan dengan variabel dukungan sosial dan resiliensi (Herbert et al., 2018). Penelitian selanjutnya dapat menjadi variabel yang dapat dipertimbangkan untuk diikutsertakan dalam penelitian tentang dukungan sosial dengan resiliensi. Selain itu, ketika penelitian ini dilakukan (bulan Juni hingga Juli tahun 2020) kasus pandemi COVID -19 yang melanda Jabodetabek masih berada dalam status waspada, sehingga cukup sulit melakukan penelitian secara mendalam kepada tenaga kesehatan, dikarenakan waktu bekerja yang panjang. Namun, penelitian ini dapat menjadi pertimbangan untuk dapat meningkatkan resiliensi tenaga kesehatan dengan terus memberikan dukungan sosial dalam masa pandemi.

\section{Kesimpulan}

Berdasarkan hasil analisa diperoleh kesimpulan sebagai berikut:

1. Hubungan penerimaan dukungan sosial keluarga berpengaruh positif signifikan terhadap resiliensi tenaga kesehatan di masa pandemi COVID-19. Hasil tersebut menandakan bahwa semakin tinggi penerimaan dukungan sosial yang berasal dari keluarga yang dirasakan, maka akan semakin tinggi resiliensi

2. Hubungan penerimaan dukungan sosial teman berpengaruh positif signifikan terhadap resiliensi tenaga kesehatan di masa pandemi COVID-19. Hasil tersebut menandakan bahwa semakin tinggi penerimaan dukungan sosial yang berasal dari teman yang dirasakan, maka akan semakin tinggi resiliensi

3. Hubungan penerimaan dukungan sosial significant others berpengaruh positif signifikan terhadap resiliensi tenaga kesehatan di masa pandemi COVID-19. Hasil tersebut menandakan bahwa semakin tinggi penerimaan dukungan sosial yang berasal dari significant others yang dirasakan, maka akan semakin tinggi resiliensi.

4. Penerimaan dukungan sosial baik yang berasal dari keluarga, teman dan significant others diketahui berkontribusi sebesar 32.2 persen memprediksi resiliensi tenaga kesehatan. 


\section{Daftar Pustaka}

Adimando, A. (2018). Preventing and alleviating compassion fatigue through self-care: an educational workshop for nurses. Journal of Holistic Nursing, 36(4), 304317. https://doi.org/10.1177/0898010117721581.

Ang, S. Y., Uthaman, T., Ayre, T. C., Mordiffi, S. Z., Ang, E., \& Lopez, V. (2018). Association between demographics and resilience - a cross-sectional study among nurses in Singapore. International Nursing Review, 65(3), 459-466. https://doi.org/10.1111/inr.12441.

Aplizuddin, A. F., Harmayetty, H., \& Ulfina, E. (2020). Hubungan dukungan sosial dan resiliense dengan tingkat stress pada family caregiver pasien hemodialisis di RSU Haji Surabaya. Critical Medical and Surgical Nursing Journal. 9(2). https://e-journal.unair.ac.id/CMSNJ.

Astuti, A. B., Santosa, S. W., \& Utami, M. S. (2000). Hubungan antara dukungan keluarga. Jurnal Psikologi, 2, 84-95.

Bordens, K. S., \& Abbott, B. B. (2011). Research design and methods: a process approach (Internat. ed., 8. ed). New York: McGraw-Hill.

Bozdag, F., \& Ergun, N. (2020). Psychological resilience of healthcare professionals during COVID-19 Pandemic. Psychological Report. https://doi.org/10.117/0033294120965477

Bry, A., \& Wigert, H. (2021). Stress and social support among registered nurses in a level II NICU. Journal of Neonatal Nursing. https://doi.org/10.1016/j.jnn.2021.03.010.

Cao, X., \& Chen, L. (2019). Relationships among social support, empathy, resilience and work engagement in haemodialysis nurses. International Council of Nurses, 1-8. https://doi.org/10.1111/inr.12516.

Connor, K. M., \& Davidson, J. R. T. (2003). Development of a new Resilience scale: The Connor-Davidson Resilience scale (CD-RISC). Depression and Anxiety, 18(2), 76-82. https://doi.org/10.1002/da.10113.

Creswell, J. W. (2014). Research Design: Qualitative, Quantitative and Mixed Methods Approaches (4th ed.). Thousand Oaks, CA: Sage.

Data Jumlah Kematian Terkonfirmasi Dan Terduga COVID-19". Diakses pada 2 Oktorber 2020, dari https://laporCOVID19.org/publik/.

Dey, N. E.Y., \& Amponsah, B. (2020). Source of perceived social support on resilience amongst parenst raising children with special needs in ghana. Heliyon, (6). https://doi.org/10.1016/i.heliyon.2020.e05569.

Duncan, D. (2020). What The COVID-19 Pandemic Tells Us About The Need To Develop Resilience In The Nursing Workforce. Nursing Management. https://doi.org/10.7748/nm.2020.e1933.

Fatima, S., Sharif, H., \& Zimet, G. (2018). Personal and social resources interplay synergistically to enhance academic motivation. International Journal of Educational Psychology, 7(2), 196-226. 
Penerimaan Dukungan Sosial Sebagai Prediktor Resiliensi pada Tenaga Kesehatan di Masa Pandemi COVID-19

Proyeksi, Vol. 16 (2) 2021, 119-132

https://doi.org/10.17583/ijep.2018.3017.

Fu, C. Y., Yang, M. S., Leung, W., Liu, Y. Y., Huang, H. W., \& Wang, R. H. (2017). Associations of professional quality of life and social support with health in clinical nurses. Journal of Nursing Management, 26(2), 172-179. https://doi.org/10.1111/jonm.12530.

Guo, Y., Luo, Y., Lam, L., Cross, W., Plummer, V., \& Zhang, J. (2017). Burnout and its association with resilience in nurses: A cross-sectional study. Journal of Clinical Nursing, 27(1-2), 441-449. https://doi.org/doi:10.1111/jocn.13952.

Hamama, L, Hamama-Raz, Y, Stokar, YN, Pat-Horenczyk, R, Brom, D, \& Bron-Harlev, E. (2019).Burnout and perceived social support: The mediating role of secondary traumatization in nurses vs. physicians. Journal of Advance Nursing; 75: 2742- 2752. https://doi.org/10.1111/jan.14122.

Heath, C., Sommerfield, A., \& von Ungern-Sternberg, B. S. (2020). Resilience strategies to manage psychological distress among healthcare workers during the COVID-19 pandemic: a narrative review. Anaesthesia, 75(10), 1364-1371. https://doi.org/10.1111/anae.15180.

Hendy, A., Abozeid, A., Sallam, G., Abboud Abdel Fattah, H., \& Ahmed A., \& Reshia, F. (2020). Predictive factors affecting stress among nurses providing care at COVID-19 isolation hospitals at Egypt. Nursing Open, August, 1-8. https://doi.org/10.1002/nop2.652.

Herbert, M.S., Leung, D.W., Pittman, J.O.E., Floto, E., \& Afari, N. (2018). Race/ethnicity, psychological resilence, and social support among OEF/OIF Combat Veteran. Psychiatry Research, 265-270. https://doi.org/10.1016/j.psychres.2018.04.052.

Herrman, H., Stewart, D. E., Diaz-granados, N., Dphil, E. L. B., Jackson, B., \& Yuen, T. (2011). What Is Resilience? 56(5). https://doi.org/https://doi.org/10.1177/070674371105600504.

Hu, D., Kong, Y., Li, W., Han, Q., Zhang, X., Zhu., L. X., Wan, S. W., Liu, Z., Shen, Q., Yang, J., He, H-Gu., \& Zhu, J. (2020). Frontliner nurses burnout, anxiety, depression, and fear statuses and their associated factors during the COVID-19 outbreak in Wuhan, China: A Large scale cross sectional study. EClinicalMedicine, 24(100424). DOI: https://doi.org/10.1016/i.eclinm.2020.100424.

Hsieh, H. F., Chang, S. C., \& Wang, H. H. (2017). The relationships among personality, social support, and resilience of abused nurses at emergency rooms and psychiatric wards in Taiwan. Women and Health, 57(1), 40-51. https://doi.org/10.1080/03630242.2016.1150385.

IDI Catat 123 Dokter Meninggal Selama Pandemi COVID-19". cnnindonesia.com. diakses pada 2 Oktober 2020, dari https://www.cnnindonesia.com/nasional/20200926180517-20-551322/idi catat-123-dokter-meninggal-selama-pandemi-COVID-19.

Jones, S. M., Woodward, M., \& Mioshi, E. (2019). Social support and high resilient coping in carers of people with dementia. Geriatric Nursing, 40(6), 584-589. https://doi.org/10.1016/j.gerinurse.2019.05.011.

Khanlou, N., \& Wray, R. (2014). A whole community approach toward child and youth resilience promotion: a review of resilience literature. International Journal of Mental Health and Addiction, 12(1), 64-79. https://doi.org/10.1007/s11469-013-9470-1. 
Kiliç, T., \& Çelik, A. S.(2020). Relationship between the social support and psychological resilience levels perceived by nurses during The COVID-19 Pandemic: A Study From Turkey. Perspect Psychiatr Care, 1-9. https://doi.org/10.1111/ppc.12648.

Kim, S.M., Kim, H.R., Min, K.J., Yoo, S.K., Shin, Y.C., Kim, E.J., \& Jeon, S.W. (2019). Resilience as a protective factor for suicidal ideation among koreans workers. Korean Neuropsychiatric Association. https://doi.org/10.307773/pi.2019.0072.

Lai, J., Ma, S., Wang, Y., Cai, Z., Hu, J., Wei, N., Wu, J., Du, H., Chen, T., Li, R., Tan, H., Kang, L., Yao, L., Huang, M., Wang, H., Wang, G., Liu, Z., \& Hu, S. (2020). Factors associated with mental health outcomes among health care workers exposed to coronavirus disease 2019. JAMA network open, 3(3), e203976. https://doi.org/10.1001/jamanetworkopen.2020.3976.

Labrague, L. J., \& De los Santos, J. A. A. (2020). COVID-19 anxiety among front-line nurses: Predictive role of organisational support, personal resilience and social support. Journal of Nursing Management, August, 1-9. https://doi.org/10.1111/jonm.13121.

Labrague L. J., \& de los Santos, J.A.A. (2021). Prevalence and predictors of coronaphobia among fronline hospital and public health nurses. Public Health Nursing, 38(3), 282-389. https://doi.org/10.1111/phn.12841.

Labrague, L. J. (2021). Psychological resilience, coping behaviour, and social support among healthcare workers during COVID-19 pandemic: A systematic review of quantitative studies. Journal of Nursing Management, 28(7), 1653-1661. https://doi.org/10.1111/jonm.13336.

Lök, N., \& Bademli, K. (2020). The relationship between the perceived social suport and psychological resilience in caregivers of patients with schizophrenia. Community Mental Health Journal. https://doi.org/10.1007/s10597-020-006655-w.

Maben, J., \& Bridges, J. (2020). COVID-19: Supporting nurses' psychological and mental health. Journal of Clinical Nursing, 29(15-16), 2742-2750. https://doi.org/10.1111/jocn.15307.

Manomenidis, G., Panagopoulou, E., \& Montgomery, A. (2018). Resilience in nursing: the role of internal and external factors. Journal of Nursing Management, 27(1), 172-178. https://doi.org/10.1111/jonm.12662.

Masten, A. S. (2013). Global Perspectives on Resilience in Children and Youth. Child Development, 85(1), 6-20. https://doi.org/10.1111/cdev.12205.

Maunder, R., Hunter, J., Vincent, L., Bennett, J., Peladeau, N., Leszcz, M., Sadavoy, J., Verhaeghe, L. M., Steinberg, R., \& Mazzulli, T. (2003). The immediate psychological and occupational impact of the 2003 SARS outbreak in a teaching hospital. Cmaj, 168(10), 1245-1251.

Mitchell, J.C., \& Zimet, G.D. (2000). Psychometric properties of the multidimensional scale of perceived social support in urban adolescent. American Journal Of Community Psychologi, 28(3): 391-400. https://doi.org/10.1023/A:1005109522457.

Pasay-an, E., Alshammari, F., Mostoles Jr, R., Gattud,V. Cajigal, J., Buta, J. (2021). A qualitative study on nurses' experiences with social stigma in the context of COVID-19, Enfermería Clínica. https://doi.org/10.1016/j.enfcli.2021.05.004. 
PNNI: 71 Orang Perawat Meninggal Dunia Karena COVID-19" (n.d). Diakses pada 25 Oktober 2020, dari https://www.kompas.com/tren/read/2020/09/13/173321665/ppni-71-orang perawatmeninggal-dunia-karena-COVID 19?page=all\#: :text=Sekretaris\%20Tim\%20Penanganan\%20COVID\%2D19, \%2F2020)\%20berjumlah\%2080\%20orang.

Pollock, A., Campbll, P., Cheyne, J., Cowie, J., Davis, B., J., .......Maxwell, M. (2020). Interventions to support the resilience and mental health of frontline health and social care professionals during and after a disease outbreak, epidemic or pandemic: A mixed methods systematic review. Diambil pada Juni 2020 dari Cochrane Database of Systematic Reviews.

Putri, I. S., \& Anulus, A. (2020). Preventive actions to minimizing the coronavirus disease 19 (COVID19) transmissions among health workers: a systematic review. Journal of Thee Medical Sciences (Berkala Ilmu Kedokteran), 52(03), 110-119. https://doi.org/10.19106/jmedscisi005203202013.

Roberts, N.J., Kocaman, K.M., Lippiett, K., Ray, E., Welch, L., \& Kelly, C. (2021). Levels Of Resilience, Anxiety And Depression In Nurse Working In Respiratory Clinical Areas During The COVID Pandemic. Respiratory Medicine. https://doi.org/10.1016/j.rmed.2020.106219.

Roser, M., Ritchie, H., Ortiz-Ospina, E., Hasell, J. (2020). Coronavirus Pandemic (COVID-19)". Diakses dari : 'https://ourworldindata.org/coronavirus'.

Rossi, R., Socci, V., Pacitti, F., Di Lorenzo, G., Di Marco, A., Siracusano, A., \& Rossi, A. (2020). Mental health outcomes among frontline and second-line health care workers during the coronavirus Disease 2019 (COVID-19) Pandemic in Italy. JAMA Network Open, 3(5), e2010185. https://doi.org/10.1001/jamanetworkopen.2020.10185.

Şanlıtürk, D. (2021). Perceived and sources of occupational stress in intensive care nurses during the COVID-19 pandemic. Intensive and Critical Care Nursing, https://doi.org/10.1016/j.iccn.2021.103107.

Santoso, E., \& Setiawan, J. L. (2018). Peran Dukungan Sosial Keluarga, Atasan, dan Rekan Kerja terhadap Resilient Self-Efficacy Guru Sekolah Luar Biasa. Jurnal Psikologi, 45(1), 27-39. https://doi.org/10.22146/jpsi.25011.

Setiawati, Y., Wahyudi, J., Joestandari, F., Maramis, M.M., \& Atika, A. (2021). Anxiety and resilience of healthcare workers during covid-19 pandemic in indonesia. Journal Of Multidisciplinary Healthcare. https://doi.org/10.2147/JMDH.S216655.

Sim, A., Bowes,L., \& Gardner, F. (2019). The promotive effect of social support for parental resilience in a refugee context: a cross-sectional study with mother in lebanon. Prevention Science. https://doi.org/10.1007/s11121-019-0983-0.

Talaee et al. (2020). stress and burnout in health care workers during covid-19 pandemic: Validation Of A Questionnaire. Journal Od Public Health: From Theory To Practice. https://doi.org/10.1007/s10389-02-01313-z

Tinajero,C., Cadaveira, F., Rodriguez, S. M., \& Paramo, F. M. (2019). Perceived social support from significant others among binge drinking and polyconsuming spanish university students. 
International Journal of Envionmental Research And Public Health. https://doi.org/10.3390/ijerph16224506.

Ungar, M. (2012). Researching and theorizing resilience across cultures and context. Preventive Medicine, 55(5), 387-389.

Viswanathan, R., Myers, M.F., \& Fanous, A.H. (2020). Support groups and individuals mental health care via video conferencing for frontline clinicians during the COVID-19 Pandemic. Psychomasomatic Journal. https://doi.org/10.1016/j.psym.2020.06.014.

WHO They Are (n.d). diakses pada 28 Oktober 2020: https://www.frontlinehealthworkers.org/whotheyre\#: :text=Frontline\%20health\%20workers\%20are\%20those,in\%20remote\%20and\%20rural \%20areas.\&text=They\%20are\%20the\%20first\%20and,providing\%20many\%20life\%2Dsaving\%20i nterventions.

What Role do Health Workers at The Frontline of Service Provinsion Play Toward Universal Health Coverage?"(n.d). $\quad$ diakses $\quad 28$ pada $\quad 2020$ : https://www.who.int/workforcealliance/media/qa/10/en/ .

Winning, AM., Merandi, JM., Lewe, D., Nancy, S., Christine, L., Gerhardt, C. (2018). The emotional impact of errors or adverse events on healthcare providers in the NICU: The protective role of coworker support. Journal Advance Nursing. 74: 172-180. https://doi.org/10.1111/jan.13403.

Zimet, G. D., Dahlem, N. W., Zimet, S. G., \& Farley, G. K. (1988). The Multidimensional Scale of Perceived Social Support. Journal of Personality Assessment, 52(1), 30-41. https://doi.org/10.1207/s15327752jpa5201_2.

83\% Tenaga Kesehatan Indonesia Mengalami Burnout Syndrome Derajat sedang dan Berat Selama Masa Pandemi COVID-19" (n.d) diakses pada Oktober 2020, dari https://fk.ui.ac.id/berita/83tenaga-kesehatan-indonesia- mengalami-burnout-syndrome-derajat-sedang-dan-berat-selamamasa pandemi-COVID-19.html. 